\title{
Tuberculosis of the oral cavity: an uncommon but still a live issue
}

\author{
Ewa Krawiecka, Elżbieta Szponar
}

Department of Oral Mucosa Diseases, Poznan University of Medical Sciences, Poznan, Poland Head of the Department: Barbara Dorocka-Bobkowska MD, DDS, PhD

Postep Derm Alergol 2015; XXXII (4): 302-306 DOI: 10.5114/pdia.2014.43284

\begin{abstract}
This paper aims at characterizing clinical features, occurrence, diagnostic process and treatment of oral tuberculosis (TB), basing on the available literature. Oral TB manifestations are uncommon and usually secondary to pulmonary changes. They predominantly appear as ulcers. Eruptions are usually single, painful and resistant to conventional treatment. Diagnosis always needs to be confirmed histopathologically. Anti-tubercular systemic therapy is required in every patient diagnosed with oral TB, while topical treatment is only adjuvant. A low incidence of oral TB together with a non-specific clinical picture might pose difficulties in its diagnosis. Oral changes in TB are likely to be overlooked what can result in further spread of Mycobacterium tuberculosis due to a delay in instituting proper treatment. Tuberculosis morbidity has risen recently and more multi-drug resistant strains of TB bacilli are found, what can result in a higher incidence of oral TB. Clinicians should be therefore aware of a possible occurrence of this entity and consider it while making a differential diagnosis of atypical oral changes.
\end{abstract}

Key words: oral tuberculosis, atypical ulcers, non-healing oral ulcers.

\section{Introduction}

Tuberculosis (TB) is a chronic infectious disease caused by a Mycobacterium tuberculosis complex. This complex consists of $M$. tuberculosis, which is the main causative agent of TB, as well as of M. bovis, $M$. africanum, and M. microti [1-3]. Mycobacterium tuberculosis is a Grampositive, acid-fast, aerobic bacillus which was first identified and described by Robert Koch in 1882 [4, 5]. Humans and bovine animals are the reservoir of TB bacilli [6]. The microorganisms are transmitted by the droplet contact, rarely by the intake of unpasteurized cow's milk infected with Mycobacteria [3, 5-7]. Only a few percent of the infected subjects develop an active disease soon after the initial exposure to the tubercle bacilli (primary TB) [5]. Tuberculosis usually occurs in its secondary form, as a result of reactivation of a latent infection $[3,5,8]$. It is estimated that about $1 / 3$ of the world population has been affected with $M$. tuberculosis, however these are mainly asymptomatic infections $[3,8,9]$. The infection becomes latent when some part of the inhaled bacilli survive macrophage attack after reaching the pulmonary alveoli. Tubercle bacilli may remain dormant for several years, circumscribed by the granular tissue $[3,5,10]$.
Tuberculosis as a life-threatening condition is still regarded a live issue [11]. According to the WHO, about 8 million new TB cases and about 2.9 million deaths related to this disease emerge in the world annually [12, 13]. The incidence of TB has systematically been decreasing since the last decades of the $20^{\text {th }}$ century, and there has been a 41\% decline in mortality since 1990 [14]. However, an increase in TB morbidity has been recently observed [15]. In Poland, TB incidence was 22.2 cases per 100,000 population (8478 cases) in 2011 which is a slight increase comparing to previous years [16]. The factors that favour the spread of tuberculosis, both its pulmonary and extrapulmonary form, are: an HIV epidemic, higher life expectancy, poverty expansion [13]. Other predisposing factors include prolonged immunosuppressive therapy, diabetes, alcoholism and drug addiction, lymphomas and other malignant tumors [2, 6, 17-19]. Tuberculosis occurs more often in men than in women, and more frequently affects people from lower socio-economic groups [6]. Moreover, multi-drug resistant strains of $M$. tuberculosis are more prevalent as observed in recent years [18, 20].

Pulmonary TB is most commonly observed but all parts of the body, including the oral cavity, can be af-

Address for correspondence: Ewa Krawiecka, Department of Oral Mucosa Diseases, Poznan University of Medical Sciences, 70 Bukowska St, 60-812 Poznan, Poland, phone: +48 6185470 39, e-mail: krawiecka.ewa@gmail.com Received: 30.09.2013, accepted: 25.01.2014. 
fected $[2,6,10,13]$. Extrapulmonary lesions are reported to account for $5 \%$ to $50 \%$ of all TB cases $[9,15,17,21]$. In Poland, extrapulmonary TB was found in $6.9 \%$ of all registered cases in 2010 [21], while in Western Europe and the USA it was found in $18-20 \%$ [17]. It is suggested that extrapulmonary TB is underdiagnosed in Poland what can be due to difficulties in its diagnosis $[6,13,17]$.

Extrapulmonary TB tends to occur more often in immunocompromised people, in children and the elderly, in patients infected with HIV, after graft procedures, during prolonged steroid treatment $[9,21]$. Changes are most commonly found in the pleura, lymph nodes, bones, genito-urinary system, skin and central nervous system. The oral cavity is also a possible site to be affected [21].

Oral manifestations of tuberculosis are uncommon, they are observed in $0.5-1.5 \%$ of the patients suffering from this disease $[2,6-8,11,13,22-24]$. Its clinical presentation is non-specific, what may cause difficulties in diagnosis and result in a delay in instituting a proper treatment. This paper aims at emphasizing the importance of including TB in a differential diagnosis of oral lesions which present similar clinical features.

\section{Clinical picture}

Oral TB may be either primary or secondary. The secondary form is observed more often than the primary one [2, 3, 7, 9]. Oral focus of $M$. tuberculosis infection may appear as a result of autoinfection from sputum, but a hematogenous or lymphatic route of transmission is also possible [2, 16, 23]. It is believed that the intact oral mucosa, constant flow of saliva and its antibacterial properties protect from tubercle bacilli invasion to the oral tissues. However, any local trauma can promote infection. Other local predisposing factors include poor oral hygiene, hyperkeratosis disorders such as leukoplakia, oral mucosa inflammation or even tooth extraction [7, 20, 22, 25].

Pathological lesions in oral TB may occur at any mucosal site $[1,9]$. It is reported that they are most commonly found on the tongue, followed by the labial mucosa (often at the labia contact site), hard palate, gingivae and buccal mucosa, as to the frequency $[2,6,13,15,18$, 26-30]. Kakisi et al. analyzed medical records filed at the Oral Pathology Department (Kaoshiung University) of the patients who were diagnosed with the head and neck tuberculosis from 1991 to 2007. These lesions were most frequently localized on the buccal mucosa/oral cavity vestibule, then in the gingivae, palate, labial mucosa and tongue [12]. However, primary oral tuberculosis, which is less common, appears predominantly on the gingival or buccal mucosa $[7,8,17,27]$.

Ulcers are the most common oral manifestations of TB in the oral cavity $[2,6,7,13,20]$. In primary TB, a non-painful ulcer is accompanied by the local (submandibular, submental and cervical) lymph nodes en- largement [7, 17, 27, 31]. This form of the disease usually appears in children, whereas the secondary form is most commonly observed in the middle-aged and elderly [7, $17,27,31]$. Ulcerations in the secondary TB cause profound pain $[4,15,20,25,27,31]$. Painful changes may interfere with speech and food ingestion, and often cause hypersalivation. The lymph nodes may be non-palpable or enlarged, with a tendency to their softening in the advanced stage of the disease $[6,13,25,28]$. Tubercular ulcers are usually single, but multiple changes can also be found. Eruptions are superficial or deep, oval or elongated, and their central part covered with a necrotic tissue may make a few millimeters deep depression [7, $13,18,27]$. The lesion margins are irregular, undermined, indurated and ragged. The ulcer floor may be covered with yellowish or bluish Trelat granules [4, 6, 11, 28, 32]. A large oval tubercular ulceration on the buccal mucosa is presented in Figure 1. The ulcer is covered with a yellowish exudate and has a slightly undermined border. The surrounding buccal mucosa is inflamed.

Tubercular ulcerations last for a long time showing no tendency to heal, and increase slowly in size $[2,6,13,18$, $25,29,32]$. Occurrence, risk factors, clinical features and management of the primary and secondary oral tuberculosis are presented in Table 1.

Although the proper, ulcerative form of oral TB occurs most commonly, it may also show as a lupoid form, which is less frequently observed [32-34]. In this form, pinkish or yellowish granules appear on the inflamed basis. They form aggregates of $2 \mathrm{~cm}$ in diameter, then break down forming ulcers which heal leaving a scar. Intraoral lesions are accompanied by changes localized on the skin of the face, especially the nose [32]. Aird has developed an oral TB classification basing on five different oral changes: ulcers, tuberculomas (granules that collapse forming ulcerations), tuberculous fissures, tubercle papillomas (overgrowths of the tuberculous fissure margins) and cold abscesses [15]. Apart from ulcers,

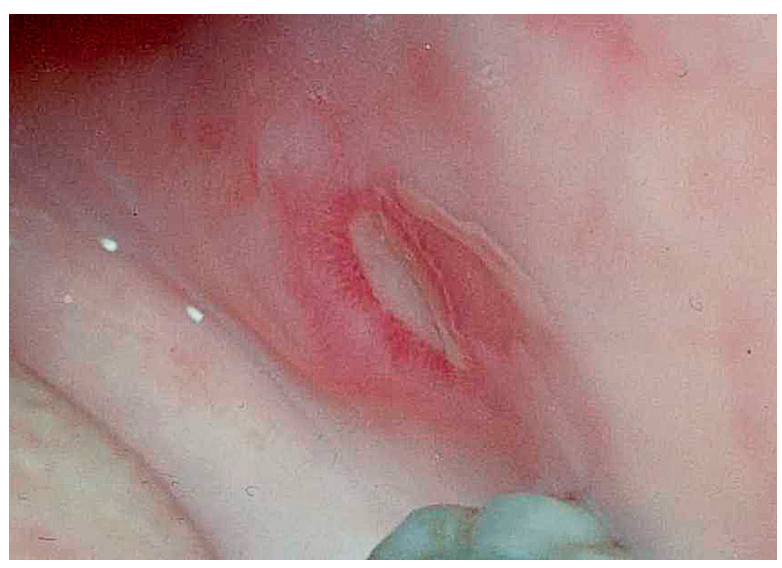

Figure 1. Tuberculosis, an ulcer on the buccal mucosa (photograph from the Clinic archives) 
Table 1. Occurrence, risk factors, clinical picture and management of the primary and secondary form of oral tuberculosis

\begin{tabular}{|c|c|c|}
\hline Variable & Primary oral TB & Secondary oral TB \\
\hline Occurrence & Very rare, found predominantly in children & $\begin{array}{l}\text { More often found than the primary, especially } \\
\text { in the middle-aged and elderly }\end{array}$ \\
\hline General and local risk factors & \multicolumn{2}{|c|}{$\begin{array}{l}\text { Immunodeficiency (e.g. in diabetes, neoplasms, alcoholism, states after graft procedures, HIV } \\
\text { infection, prolonged steroid therapy), tobacco smoking, oral mucosa traumas, hyperkeratotic } \\
\text { disorders, poor oral hygiene, periodontitis }\end{array}$} \\
\hline Clinical manifestations & $\begin{array}{l}\text { Ulcer - superficial and covered with granular } \\
\text { tissue or larger and deeper }\end{array}$ & $\begin{array}{c}\text { Ulcer - with undermined, irregular edges, covered } \\
\text { with Trelat granules }\end{array}$ \\
\hline Soreness of the lesion & No & Yes \\
\hline Local lymph nodes & Enlarged, painful & Enlarged or not, usually not painful \\
\hline Management & \multicolumn{2}{|c|}{$\begin{array}{l}\text { Anti-tubercular therapy (antibiotics), topically administered anti-inflammatory and protective agents, } \\
\text { elimination of chronic traumatic factors }\end{array}$} \\
\hline
\end{tabular}

other forms of oral TB are sometimes distinguished in the literature: nodules or papules, fissures, tissue overgrowth or infiltration, periapical granulomas [4, 11, 13, 25, 27, 33]. Tuberculosis can also affect the bones [34]. Most commonly involved cranio-facial bones are the maxilla and the zygomatic bone, however this form of TB is very rare. In the course of the tubercular inflammation of the bones and osteomyelitis extraoral fistulas often appear (mainly on the cheek) [2, 34]. It should be emphasized that oral manifestations of TB are infectious [28].

Practitioners should consider general symptoms which can be associated with tuberculosis while taking medical history. Persistent cough is an early symptom of the disease. Although it is not typical of this entity, tuberculosis should be taken into consideration if it lasts more than 3 weeks with no obvious cause. Patients may also suffer from fever, chills, night sweats, weight loss, and fatigue. Hemoptysis may be observed in people with cavities in the lungs, but it is seldom the first sign of TB $[3,5,11,28,29]$. Oral lesions secondary to pulmonary changes can precede systemic symptoms [27, 31]. Systemic symptoms rarely appear in the primary oral tuberculosis [7, 27].

\section{Differential diagnosis}

The clinical picture of oral tuberculosis is variable and non-specific [2, 8, 17, 25]. Differential diagnosis includes many entities. Determining the cause of oral ulceration requires taking medical history, clinical examination and accessory investigations. It is essential to define the number of ulcers, their duration, and margins appearance. Diseases that present ulcers in their course and should be taken into consideration are: syphilis, actinomycosis, histoplasmosis, planoepithelial cancer, traumatic lesions, recurrent aphthous stomatitis (RAS), leukemia, pemphigoid, erosive form of lichen planus, Crohn's disease or sarcoidosis [6, 17, 20, 26-29, 31]. Differential diagnosis of oral ulcers is presented in Table 2.
Tubercular ulcers are persistent, last more than 3 weeks, do not respond to topical treatment and are usually single and painful $[2,28,29]$, contrary to luetic ulcers which are painless, with smooth but indurated margins [27]. Planoepithelial cancer manifesting as an ulceration develops more slowly than this found in TB. It may take the form of a cauliflower-shaped overgrowth. The margins are firm, raised, tissue infiltration is palpable. Initially, ulcerations do not cause pain and are prone to bleeding $[4,27]$. It should be noted that in $3 \%$ of cases, oral tubercular lesions co-exist with oral malignancy [4, 26]. Oral ulcers are most commonly caused by trauma. Traumatic lesions are painful, surrounded by an inflamed ring and heal when an irritant is eliminated or when antiinflammatory treatment is implemented [27-29]. Multiple, painful and recurrent ulcers may indicate RAS (especially Sutton's aphtae) or some of the muco-cutaneous diseases (ulcerative lichen planus, pemphigoid) [7, 20, 28, 29]. Solitary or multiple ulcerations similar to tubercular changes as to their appearance and course may also occur in other granulomatous diseases such as Crohn's disease or sarcoidosis [11, 13, 17, 18, 25]. Histoplasmosis (deep mycotic infection) may cause ulcers resembling the tubercular ones, with systemic symptoms including fatigue and a productive cough. They heal following a longterm antifungal therapy $[29,35]$.

\section{Diagnosis confirmation}

When oral tuberculosis is suspected, diagnosis is made on the basis of carefully collected medical history which includes general and local symptoms as well as other patient's complaints. It is important to take into account the symptoms helpful to differentiate oral TB from other entities in which they are also present, i.e. fever, lymph nodes enlargement, cutaneous changes, gastro-intestinal disorders, chronic cough, excessive fatigue $[6,11,28,29]$. 
Table 2. Differential diagnosis of oral ulcers

\begin{tabular}{|c|c|c|c|c|}
\hline Oral disease & $\begin{array}{l}\text { Number } \\
\text { of ulcers }\end{array}$ & $\begin{array}{l}\text { Soreness of the } \\
\text { ulcer }\end{array}$ & Course, duration & Clinical picture \\
\hline Oral TB & Single & $\begin{array}{c}\text { Primary oral TB - } \\
\text { no, secondary oral } \\
\text { TB - yes }\end{array}$ & $\begin{array}{l}\text { Chronic ulcer lasting for more than } \\
3 \text { weeks, general symptoms may appear, } \\
\text { persistent cough, pulmonary changes }\end{array}$ & $\begin{array}{c}\text { Ragged, indurated and irregular } \\
\text { margins, Trelat granules, cobblestone } \\
\text { appearance }\end{array}$ \\
\hline Syphilis & Single & No & $\begin{array}{c}\text { Ulcer lasting for } 2-6 \text { weeks, spontaneous } \\
\text { healing }\end{array}$ & Smooth, indurated margins \\
\hline Histoplasmosis & $\begin{array}{l}\text { Single/ } \\
\text { multiple }\end{array}$ & Yes & $\begin{array}{c}\text { Chronic ulcer lasting for more than } \\
3 \text { weeks, general symptoms may appear, } \\
\text { persistent cough, pulmonary changes }\end{array}$ & Irregular, indurated margins \\
\hline $\begin{array}{l}\text { Planoepithelial } \\
\text { cancer }\end{array}$ & Single & $\begin{array}{l}\text { Initially - no, } \\
\text { becomes painful } \\
\text { later in the course }\end{array}$ & Chronic ulcer, developing slowly & $\begin{array}{l}\text { Irregular margins, indurated base, } \\
\text { cauliflower-shaped overgrowth } \\
\text { possible }\end{array}$ \\
\hline $\begin{array}{l}\text { Recurrent } \\
\text { aphthous } \\
\text { stomatitis } \\
\text { (Sutton's } \\
\text { aphtae) }\end{array}$ & $\begin{array}{l}\text { Single/ } \\
\text { multiple }\end{array}$ & Yes & $\begin{array}{l}\text { Recurrent ulcers, spontaneous healing } \\
\text { after } 7-30 \text { days }\end{array}$ & Shallow ulcer, inflamed halo \\
\hline Traumatic ulcers & $\begin{array}{l}\text { Single/ } \\
\text { multiple }\end{array}$ & Yes & $\begin{array}{l}\text { Spontaneous healing after elimination } \\
\text { of traumatic factor }\end{array}$ & $\begin{array}{c}\text { Inflamed basis, shallow or deep ulcer, } \\
\text { margins slightly elevated }\end{array}$ \\
\hline $\begin{array}{l}\text { Lichen planus } \\
\text { (ulcerative form) }\end{array}$ & $\begin{array}{l}\text { Single/ } \\
\text { multiple }\end{array}$ & Yes & $\begin{array}{l}\text { Recurrent ulcers, may be preceded by } \\
\text { subepithelial bullas }\end{array}$ & $\begin{array}{c}\text { Shallow, vast ulcer, Wickham's striae } \\
\text { present }\end{array}$ \\
\hline Pemphigoid & $\begin{array}{l}\text { Single/ } \\
\text { multiple }\end{array}$ & Yes & $\begin{array}{l}\text { Recurrent ulcers, preceded by } \\
\text { subepithelial bullas }\end{array}$ & $\begin{array}{l}\text { Moderate shallow ulcer, margins } \\
\text { non-indurated, bullas' remnants }\end{array}$ \\
\hline
\end{tabular}

Final diagnosis is confirmed with a number of accessory investigations. In every oral ulcer lasting for more than 3 weeks, an incisional biopsy is required [11, 17, 18, 22, 25]. Histopathological assessment may reveal the presence of granulomatous inflammatory infiltration with Langhans giant cells and lymphocytes. Foci of caseous necrosis of the tissue can be observed. Mycobacteria can be demonstrated in the collected specimen [7, 11, 12, 21, 25]. Microbiological culture of sputum and of the material taken from the surface of the oral lesion should be done, but the results are obtained after 10 weeks [5]. Ziehl-Nielsen staining of sputum swab for acid-fast bacilli can be positive $[3,7,8,11-13,20,22]$. In every patient suspected of TB, posterior-anterior (PA) and lateral view chest radiograph is mandatory. Disseminated infiltrations, nodules, fibrotic scars, cavities in the lungs, hilar or mediastinal lymphadenopathy, pleural effusion are the findings suggestive of TB $[1,3,5,7,12]$. Mantoux tuberculin skin test is helpful in the diagnosis, but its positive result does not always mean active TB. It may also indicate previous infection or administration of BCG vaccine [3,5]. Recently, interferon- $\gamma$ release assays (IGRAs) are used instead of the Mantoux test due to their higher sensitivity and specificity. They are not affected by BCG vaccination $[9,36]$. In doubtful cases, molecular tests (PCR) may be helpful $[1,7,13]$.

\section{Management}

The most important aspect of oral TB management is a systemic anti-tubercular therapy (ATT). The standard regimen consists of two phases. The first line of treatment requires 3 or 4 antibiotics (to prevent drug resistance), usually isoniazid, rifampicin, pyrazinamide and ethambutol. These antibiotics are typically administered for the 2 initial months. For the next 4 months the treatment is continued with 2 anti-tuberculous drugs, usually isoniazid and rifampicin [3, 5, 12, 13, 28, 37]. Improper management of TB or lack of compliance with antibiotics application regime can produce multi-drug resistant strains of bacilli (MDR) $[10,14,38]$. In Poland, TB treatment is compulsory $[17,39]$. Patients with possible TB should be isolated until sputum smears are negative.

Local therapy of TB oral manifestations includes topically administered anti-inflammatory ointments and oral mucosa protecting agents. Improvement in oral hygiene and elimination of possible traumatic factors (review of prosthetic devices, improper dental fillings, sharp teeth edges) is also important $[6,13,17]$.

\section{Summary}

Oral TB is an uncommon entity, difficult to diagnose and treat. In some patients, oral manifestations may be 
the only signs of the disease, a dentist or a dermatologist can therefore be the first practitioner to suspect TB $[1,2,11]$. Immediate referral of the patient to a specialist and prompt treatment leads to full recovery, diminishes the number of complications in the TB course and helps in controlling the spread of this potentially lethal disease $[7,18]$.

In Poland, extrapulmonary TB is not diagnosed as often as in other European countries, what may be indicative of TB under-diagnosing $[6,13,17]$. It is therefore important to be aware of possible occurrence of oral TB and being familiar with its clinical features and diagnostic means that are available. It should be taken into account in differential diagnosis of persistent, non-healing oral ulcers.

\section{Conflict of interest}

The authors declare no conflict of interest.

\section{References}

1. Petkowicz B, Świątkowski W, Tomaszewski T, Mensur R. Oral tuberculosis. Case report. Ann Univ Mariae Curie Sklodowska 2006; 61: 287-9.

2. Ebenezer J, Samuel R, Mathew GC, et al. Primary oral tuberculosis: report of two cases. Indian J Dent Res 2006; 17: 41-4.

3. Korzeniewska-Koseła M. Gruźlica - co powinien wiedzieć stomatolog [Polish]. Med Prakt Stomatol 2012; 3: 50-4.

4. Ram H, Kumar S, Mehrotra S, Mohommad S. Tubercular ulcer: mimicking squamous cell carcinoma of buccal mucosa. J Maxillofac Oral Surg 2012; 11: 105-8.

5. Kołaczkowska M. Gruźlica płuc [Polish]. In: Zarys pulmonologii z elementami alergologii. Batura-Gabryel H, Młynarczyk W (eds.). Poznan University of Medical Sciences, Poznan 2004; 68-84.

6. Klepacz J, Peterson R, Kurnatowska AJ. Tuberculosis in oral cavity - a case report [Polish]. Porad Stomatol 2008; 8: 169-72.

7. Nanda KD, Mehta A, Marwaha M, et al. A disguised tuberculosis of the oral buccal mucosa. J Clin Diagn Res 2001; 5: 357-60.

8. Khammissa RA, Wood NH, Meyerov R, et al. Primary oral tuberculosis as an indicator of HIV infection. Patholog Res Int 2011; 2011: 893295.

9. Rowińska-Zakrzewska E. Extrapulmonary tuberculosis, risk factors and incidence [Polish]. Pneumonol Alergol Pol 2011; 79: 377-8.

10. DeLong L. Respiratory, gastrointestinal, neurologic and skeletal disorders. In: General and oral pathology for the dental hygienist. DeLong L, Burkhart NW. Lippincott Williams \& Wilkins, Baltimore, Philadelphia 2008; 243-45.

11. Kakisi OK, Kechagia AS, Kakisis IK, et al. Tuberculosis of the oral cavity - a systematic review. Eur J Oral Sci 2010; 118: 103-9.

12. Wang WC, Chen JY, Chen YK, Lin LM. Tuberculosis of the head and neck: a review of 20 cases. Oral Surg Oral Med Oral Pathol Oral Radiol Endod 2009; 107: 381-6.

13. Michalak A, Wojtas G, Kidawa I, et al. Tuberculosis of tongue in patient with disseminated pulmonary tuberculosis [Polish]. Pneumonol Alergol Pol 2004; 72: 28-31.

14. Global tuberculosis report 2012 - Executive Summary. Available from: www.who.int.

15. Yadav SPS, Agrawal A, Gulia JS, et al. Tuberculoma of the tongue presenting as hemimacroglossia. Case Rep Med 2012; 2012: 548350.
16. Gruźlica w Polsce. Biuletyn IGiChP - 2012 [Polish]. Available from: www.igichp.edu.pl.

17. Ucińska R, Siemińska A, Słomiński JM. Tuberculosis of the tongue. Case Rep Clin Pract Rev 2002; 3: 102-4.

18. Erbaycu AE, Taymaz Z, Tuksavul F, et al. What happens when oral tuberculosis is not treated? Monaldi Arch Chest Dis 2007; 67: 116-8.

19. Romańska-Gocka K, Cieślińska C, Zegarska B, et al. Pyoderma gangrenosum with monoclonal IgA gammopathy and pulmonary tuberculosis. Illustrative case and review. Postep Derm Alergol 2015; 32: 137-41.

20. Von Arx DP, Husain A. Oral tuberculosis. Br Dent J 2001; 190: 420-2.

21. Rowińska-Zakrzewska E, Korzeniewska-Koseła M, Roszkowski-Śliż K. Extrapulmonary tuberculosis in Poland in the years 1974-2010 [Polish]. Pneumonol Alergol Pol 2013; 81: 121-9.

22. Awasthi S, Singh V, Nizamuddin M. Tuberculosis of oral mucosa. Internet J Infect Dis 2010; 8(2).

23. Remiszewski P, Wąsowska H, Burakowska B. Tuberculosis of the tongue - case report [Polish]. Pneumonol Alergol Pol 1994; 62: 295-8.

24. Mohanapriya T, Singh KB, Arulappan T, Dhanasekar T. Lingual tuberculosis. Indian J Tuberc 2012; 59: 39-41.

25. Dixit R, Sharma S, Nuwal P. Tuberculosis of oral cavity. Indian J Tuberc 2008; 55: 51-3.

26. Kannan S, Thakkar P, Dcruz AK. Tuberculosis masquerading as oral malignancy. Indian J Med Paediatr Oncol 2011; 32: 180-2.

27. Włodek-Owińska B, Owiński T. Atlas chorób błony śluzowej jamy ustnej [Polish]. Volumed, Wrocław 1997; 3-7.

28. Scully C. Oral and maxillofacial medicine: the basis of diagnosis and treatment. Churchill Livingstone Elsevier 2013; 154-62, 409.

29. Langlais RP, Miller CS, Nield-Gehrig JS. Color atlas of common oral diseases. Lippincott Williams \& Wilkins, Philadelphia 2009; 176.

30. Sonis ST, Fazio RC, Fang L. Oral medicine secrets. Hannley \& Belfrus, Phildelphia 2002; 85-87.

31. Kamala R, Sinha A, Srivastava A, Srivastava S. Primary tuberculosis of the oral cavity. Indian J Dent Res 2011; 22: 835-8.

32. Knychalska-Karwan Z. Fizjologia i patologia błony śluzowej jamy ustnej [Polish]. Czelej, Lublin 2009; 167-8.

33. Sureshchandra B, Naveen Kumar N. Detection of presence or absence of Mycobacterium tuberculosis in infected and uninfected pulp using a microbiological culture method - case series. Endodontology 2001; 23: 6-9.

34. Stypułkowska J, Bartkowski SB. Zapalenia chirurgiczne tkanek jamy ustnej, twarzy i szyi [Polish]. In: Chirurgia szczękowo-twarzowa. Bartkowski SB (ed.). Collegium Medicum UJ, Krakow 1996; 188-9.

35. Sproat C, Burke G, McGurk M. Essential human diseases for dentists. Elsevier Health Sciences, Philadelphia 2006; 178-9.

36. Meng Y, Cai SX, Li X. Pathologically confirmed histoplasmosis: analysis of 14 cases. Indian J Med Paediatr Oncol 2011; 32: 180-2.

37. Nienhaus A, Schablon A, Diel R. Interferon-gamma release assay for the diagnosis of latent TB infection - analysis of discordant results, when compared to the tuberculin skin test. PLOS ONE 2008; 3: e2665.

38. Daley CL, Caminero JA. Management of multidrug resistant tuberculosis. Semin Respir Crit Care Med 2013; 34: 44-59.

39. Augustynowicz A, Wrześniewska-Wal I. Restriction of patient's autonomy in diagnosis and treatment of tuberculosis [Polish]. Pneumonol Alergol Pol 2013; 81: 130-6. 